\title{
Characterization of a Novel Broad-Spectrum Antifungal Protein from Virus-Infected Helminthosporium (Cochliobolus) victoriae
}

\author{
Patricia B. de Sá, Wendy M. Havens, and Said A. Ghabrial
}

Department of Plant Pathology, University of Kentucky, Lexington 40546-0312.

Current address of P. B. de Sá: United States Department of Agriculture-Animal and Plant Health Inspector Service, PPQ MDL, Beltsville, MD 20705.

Accepted for publication 5 May 2010.

\begin{abstract}
de Sá, P. B., Havens, W. M., and Ghabrial, S. A. 2010. Characterization of a novel broad-spectrum antifungal protein from virus-infected Helminthosporium (Cochliobolus) victoriae. Phytopathology 100:880-889.

A broad-spectrum anti-fungal protein of $\approx 10 \mathrm{kDa}$, designated victoriocin, was purified from culture filtrates of a virus-infected isolate of the plant-pathogenic fungus Helminthosporium victoriae (teleomorph: Cochliobolus victoriae) by a multistep procedure involving ultrafiltration and reverse-phase high-performance liquid chromatography (RP-HPLC). Amino acid sequences, obtained by automated Edman degradation sequencing of RP-HPLC-purified victoriocin-derived peptides, were used to design primers for degenerate oligonucleotide-primed polymerase chain reaction (DOP-PCR) amplification from $H$. victoriae DNA and cDNA templates. An open reading frame coding for a victoriocin pre-

was amplified by PCR from $H$. victoriae genomic DNA but not from the control fungus Penicillium chrysogenum. Southern hybridization analysis confirmed the presence of the victoriocin gene in all $H$. victoriae strains tested. Sequence analysis indicated that victoriocin has a sequence motif similar to that found in scorpion short toxin/charybdotoxin and a consensus sequence similar to that found in defensins. Victoriocin, like some other antifungal proteins, including the totivirus-encoded killer proteins, is predicted to be expressed in vivo as a preprotoxin precursor consisting of a hydrophobic N-terminal secretion signal followed by a pro-region and terminating in a classical Kex2p endopeptidase cleavage site that generates the $\mathrm{N}$ terminus of the mature victoriocin. A putative cell wall protein of $\approx 30 \mathrm{kDa}$ (P30) co-purified with victoriocin from cultural filtrates. The potential role of $\mathrm{P} 30$ in the antifungal activity of $H$. victoriae culture filtrates is discussed.
\end{abstract} cursor of 183 amino acids with calculated molecular mass of $\approx 20 \mathrm{kDa}$
The plant-pathogenic fungus Helminthosporium victoriae (teleomorph: Cochliobolus victoriae) was first described in 1946 as the causal agent of Victoria blight of oat (35). A transmissible disease of $H$. victoriae was discovered in 1959 and evidence for its viral etiology has been presented $(19,20)$. Diseased $H$. victoriae isolates have reduced growth, excessive sectoring, aerial mycelial collapse, and generalized lysis $(19,39)$. Diseased isolates, which are hypovirulent, harbor two isometric viruses with double-stranded RNA (dsRNA) genomes (26): the totivirus Helminthosporium victoriae virus $190 \mathrm{~S}$ (HvV190S) and the chrysovirus Helminthosporium victoriae virus 145S (HvV145S). HvV190S, the prototype of the newly created genus Victorivirus within the family Totiviridae, has a nonsegmented dsRNA genome $5.2 \mathrm{kbp}$ in size (24). It has been well characterized biochemically, structurally, and at the molecular level (21-23, 29,30,50). The genome of HvV145S, a member of the genus Chrysovirus in the family Chrysoviridae, consists of four dsRNA segments separately encapsidated $(26,44)$. Although the complete nucleotide sequences of full-length cDNA clones of the four genomic dsRNA segments of HvV145S have been determined, it has been difficult to purify virions in adequate quantities for detailed biochemical and structural studies (26).

We have previously noted that culture filtrates of virus-infected $H$. victoriae isolates exhibit a broad-spectrum antifungal activity (S. A. Ghabrial, unpublished). The fact that the yeast and smut strains that secrete killer proteins (killer toxins) are infected with

Corresponding author: S. A. Ghabrial; E-mail address: saghab00@email.uky.edu

doi:10.1094/PHYTO-100-9-0880

(c) 2010 The American Phytopathological Society totivirus similar to HvV190S stimulated our search for a viral origin for the antifungal activity associated with $H$. victoriae. The killer proteins from virus-infected yeast and smut strains are encoded by satellite dsRNAs that are dependent on helper totivirus for replication and encapsidation $(47,56)$. No satellite dsRNAs, however, were detected in association with infections with the totivirus HvV190S $(24,44)$. In this study, a novel broadspectrum antifungal protein (victoriocin), which is overproduced in virus-infected $H$. victoriae isolates, was purified from culture filtrates, characterized, and compared with known antifungal proteins. Furthermore, the host chromosomal gene coding for victoriocin, designated the victoriocin (vin) gene, was cloned, sequenced, and characterized.

\section{MATERIALS AND METHODS}

Fungal strains. Three strains of $H$. victoriae were used: strain A-9 (American Type Culture Collection [ATCC] 42018), a diseased isolate doubly infected with HvV190S and HvV145S; strain B-2ss, a normal virus-free single conidial isolate derived from strain B-2 (ATCC 42020); and strain 408, a naturally occurring virus-free isolate (44,51). Penicillium chrysogenum (ATCC 9480) was used in routine antifungal activity assays, and its genomic DNA served as control in polymerase chain reaction (PCR) and Southern hybridization analyses. Stock cultures of the fungal strains were maintained on potato dextrose agar supplemented with $0.5 \%$ (wt/vol) yeast extract (PDA-Y). Cultures were routinely grown on potato dextrose broth supplemented with $0.5 \%$ yeast extract (PDB-Y) or in Czapek-Dox broth (CZ) minimal medium.

Purification of proteins from culture filtrates. $H$. victoriae strains were grown in $\mathrm{CZ}$ medium in 1-liter flasks under agitation 
for $72 \mathrm{~h}$ at $23^{\circ} \mathrm{C}$, and the mycelium was removed by filtering through Miracloth (Calbiochem, San Diego, CA). The filtrate was frozen overnight, thawed, and centrifuged $(15,000 \times g$ for $30 \mathrm{~min}$ ), and the supernatant was concentrated 30 - to 40 -fold by ultrafiltration through a 3-kDa MWCO membrane at 45 to 50 psi. Solid ammonium sulfate was added to the clarified filtrate to $90 \%$ saturation and the precipitated proteins were collected by centrifugation at $40,000 \times g$ for $30 \mathrm{~min}$. The pellet was resuspended in $0.1 \mathrm{M}$ sodium phosphate buffer, $\mathrm{pH} 7.0$, containing $0.4 \%$ Triton $\mathrm{X}-100$ and the suspension was clarified by centrifugation. The supernatant was subjected to semipreparative reverse-phase highperformance liquid chromatography (RP-HPLC) through C-18 Vydak columns (Waters Corporation, Milford, MA). Elution of proteins was performed using a linear gradient of acetonitrile in $0.05 \%$ trifluoroacetic acid at a flow rate of $1.0 \mathrm{ml} / \mathrm{min}$ and absorbance was monitored at $214 \mathrm{~nm}$. RP-HPLC retention fractions were collected, concentrated using a Speed Vac Concentrator (Savant Instruments Inc., Holbrook, NY), and individually subjected to RP-HPLC. The proteins in selected fractions were subjected to Tricine sodium dodecyl sulfate polyacrylamide gel electrophoresis (Tricine-SDS-PAGE) (46). The antifungal activity of the various fractions was monitored using the "well assay" at different steps of the purification process.

Antifungal activity assays. The well assay was used to test the antifungal activity of secreted proteins in culture filtrates of strains A-9, B-2ss, and 408 against $P$. chrysogenum. Plates of PDA prepared in $0.05 \mathrm{M}$ citrate buffer $\mathrm{pH} 4.5$ (PDA-citrate) were seeded with a spore suspension of $P$. chrysogenum, the plates were allowed to dry, and wells were made in the medium using a cork borer. Test samples, including culture filtrates, partially purified protein preparations, and RP-HPLC retention fractions, were placed in the wells and the plates were incubated overnight at room temperature. The diameter of the zone of inhibition of fungal growth around each well was measured at 24-h intervals. The well assay was also used to test the antifungal activity of culture filtrates of strain A-9 against several plant-pathogenic fungi, including Fusarium solani, Phomopsis longicola, Cryphonectria parasitica, and the opportunistic human pathogens Aspergillus fumigatus and Candida albicans.

The inhibitory activity of culture filtrates of A-9 against Phytophthora nicotianae was tested by growing it on plates of PDA, PDA-tomato juice, or oatmeal agar, which were prepared by mixing equal volumes of culture filtrate (or sterile water) with each culture medium. Test and control plates were then inoculated with a plug from an actively growing colony of $P$. nicotianae and the diameter of the colony growing on the new plate was measured at 24-h intervals. Inhibition of the blue mold pathogen Peronospora tabacina by clarified culture filtrates of strain A-9 was also tested. The protein concentration in the filtrates was estimated by the Bradford assay and filtrates with protein concentrations of 1 to $1,000 \mathrm{ng} / \mathrm{ml}$ were mixed with spore suspensions of $P$. tabacina to a final count of 20,000 spores $/ \mathrm{ml}$. Mixtures $(5 \mu \mathrm{l})$ with varying protein concentrations were placed on microscope slides, the slides were incubated in a moist chamber, and spore germination was monitored over a 24-h period. Mixtures of spores and A-9 filtrates were also placed on detached tobacco leaves and the formation of lesions by $P$. tabacina on the leaves was monitored for $24 \mathrm{~h}$.

Heat inactivation of the antifungal activity was tested by incubating A-9 filtrates at 37, 50, 60, 70, 80, 90, and $99^{\circ} \mathrm{C}$ for periods of 1,2 , and $3 \mathrm{~h}$ and by autoclaving. The filtrates were also incubated on ice or at room temperature for 1,2 , and $3 \mathrm{~h}$. Inactivation of antifungal activity by proteases was assayed by incubating A-9 filtrates with pronase for 1 or $3 \mathrm{~h}$ at room temperature or at $37^{\circ} \mathrm{C}$. Protease inactivation of filtrates was also tested in the presence or absence of dithiothreitol (DTT) at $0.5 \%$ (wt/vol) or in heated compared with untreated filtrates prior to adding the pronase enzyme.
Production of antisera and western blots. Polyclonal antisera were produced against two major proteins, P10 and P30 (10 and $30 \mathrm{kDa}$ in size, respectively) that were recovered from TricineSDS gels of RP-HPLC fractions positive for antifungal activity. The gel band corresponding to P30 protein was excised from the Tricine-SDS gel, homogenized with phosphate-buffered saline (PBS) and emulsified with incomplete Freund's adjuvant. Five subcutaneous injections were applied to a White New Zealand rabbit, an initial injection with $\approx 100 \mu \mathrm{g}$ of protein, followed by an injection of $50 \mu \mathrm{g}$ of protein applied every 2 weeks. The gel band corresponding to the P10 protein was also excised from the Tricine-SDS gels and a custom polyclonal antiserum was prepared against this protein by Cocalico Biologicals, Inc. (Reamstown, PA). The antisera prepared against P10 and P30 were used in western blots, as previously described (30).

PCR amplification of protein coding regions. Partial amino acid sequences of $\mathrm{P} 10$ and $\mathrm{P} 30$, purified from culture filtrates of strain A-9, were determined by automated Edman degradation sequencing (34) at the Macromolecular Structure Analysis Facility of the University of Kentucky. The P10 and P30 bands were excised from Tricine-SDS gels and digested in-gel with trypsin. The protease digestion products were separated by RP-HPLC and highly resolved peptides were sequenced. The N-terminal amino acid sequences of P10 and P30 were determined with proteins bound to polyvinylidene difluoride membranes after transfer from Tricine-SDS gels either by electroblotting or by direct adsorption from gel pieces (52).

The amino acid sequence data were used to design degenerate primers for use in degenerate oligonucleotide primed (DOP)PCR. Sequence information for N-terminal and internal peptides of the P10 and P30 proteins was used to design two pairs of degenerate primers, Deg10-F plus Deg10-R and Deg30-F plus Deg30R (Table 1). Total DNA from strains A-9 and B-2ss, cDNA obtained by reverse transcription of mRNA from strain A-9, and full-length cDNA clones of HvV190S and HvV145S dsRNAs were used as templates in DOP-PCR. Taq DNA Polymerase (Sigma-Aldrich, St. Louis), and cycling parameters for touchdown (TD)-PCR were used for the DOP-PCR amplifications: incubation at $94^{\circ} \mathrm{C}$ for $4 \mathrm{~min} ; 30$ cycles of $94^{\circ} \mathrm{C}$ for $1 \mathrm{~min}, 60^{\circ} \mathrm{C}$ $\left(\Delta-0.5^{\circ} \mathrm{C}\right.$ per cycle) for $2 \mathrm{~min}$, and $72^{\circ} \mathrm{C}$ for $2 \mathrm{~min} ; 10$ cycles of $94^{\circ} \mathrm{C}$ for $1 \mathrm{~min}, 50^{\circ} \mathrm{C}$ for $2 \mathrm{~min}$, and $72^{\circ} \mathrm{C}$ for $1 \mathrm{~min}$; followed by an elongation period of $72^{\circ} \mathrm{C}$ for $12 \mathrm{~min}$.

To identify sequences $3^{\prime}$ and $5^{\prime}$ of the DOP-PCR product, mRNA was prepared by extraction of total RNA from $\approx 10 \mathrm{~g}$ of mycelium of strain A-9 grown for $72 \mathrm{~h}$ in PDB-Y, as described previously (51). The mRNA was purified from total RNA using the Dynabeads mRNA DIRECT kit (Dynal Invitrogen, Carlsbad, CA). First- and second-strand cDNA were synthesized from poly(A) RNA using the Superscript II cDNA synthesis kit (Invitrogen) according to manufacturer's instructions. The ds-cDNA

TABLE 1. List of primers used in this study

\begin{tabular}{ll}
\hline Primers & \multicolumn{1}{c}{ Sequence } \\
\hline $\begin{array}{l}\text { Degenerate } \\
\text { Deg10-F }\end{array}$ & 5' GGITAYGAYTAYGAYTAYGG 3' \\
Deg 10-R & 5' ACRTCIGGRTTNACRAANGG 3' \\
Deg30-F & 5' GARGCHGTNGTICCNGG 3' \\
Deg30-R & 5' CCDGCIGCYTTRTCRTTNCC 3' \\
Sequence-specific & \\
GSP1-F & 5' CTGGTGCTGGAGGAACTGAG 3' \\
GSP2-R & 5' ATCAGCAGCCACAGCCAC 3' \\
GSP3-R & 5' GTATGCAAGCCAGCACCAAGTC 3' \\
GSP4-F & 5' GGCGTCTTCTACTTTCAACC 3' \\
GSP5-R & 5' TAGACAGAAGCTTCATTTTGG 3' \\
5' RACE & \\
5' Anchor oligo dT & 5' GACCACGCGTATCGATGTCGACT 3 $^{\prime}$ T(A/G/C) 3' \\
5' Anchor & 5' GACCACGCGTATCGATGTCGAC 3' \\
\hline
\end{tabular}

${ }^{\mathrm{a}} \mathrm{RACE}=$ rapid amplification of cDNA ends. 
was PCR amplified using HiFi Taq polymerase and the genespecific primer GSP1-F (Table 1) and an oligo $\mathrm{dT}_{12-18}$ primer. The resulting PCR product was cloned and several clones were sequenced. Two reverse gene-specific primers, GSP2-R and GSP3-R (Table 1), were designed based on the sequence of the PCR product.

DNA sequences $5^{\prime}$ to the DOP-PCR amplicon were amplified by $5^{\prime}$ rapid amplification of cDNA ends ( $5^{\prime}$ RACE), essentially as described by Schaefer (45). Briefly, terminal deoxynucleotidyl transferase was used to add a homopolymeric adenine tail to the ds-cDNA, and the polyadenylated cDNA was PCR amplified using a nested PCR procedure with the proof reading DyNAzyme DNA polymerase (Fynnzymes Oy; MJ Research Inc., Waltham, MA). For the first round of PCR, a gene-specific primer (GSP2$\mathrm{R})$ and the anchor oligo(dT) primer (5'GACCACGCGTATCGA TGTCGACT $_{15} \mathrm{~T}(\mathrm{~A} / \mathrm{G} / \mathrm{C}) 3^{\prime}$ ) were used. The second round of PCR amplification was done using a second gene-specific primer (GSP3$\mathrm{R})$ annealing $3^{\prime}$ to GSP2-R and an anchor primer lacking the homopolymeric sequence (5'-GACCACGCGTATCGATGTCGAC-3').

All PCR amplification products were cloned and sequenced and the sequences were assembled using GELASSEMBLE in the University of Wisconsin GCG software package, version 10 (12). Two sequence-specific primers, GSP4-F and GSP2-R, were used with $H$. victoriae DNA from strain A-9 for amplification of the entire genomic region coding for the $20-\mathrm{kDa}$ protein, a preproprotein precursor from which victoriocin (the P10 protein) is derived (see Results).

cDNA library screening. The PCR product corresponding to the coding sequence of the $20-\mathrm{kDa}$ victoriocin precursor was used to generate $\left[\alpha-{ }^{32} \mathrm{P}\right] \mathrm{dCTP}-$ labeled probes by random-primed DNA synthesis. These probes were used to screen a cDNA library of strain A-9 (51) constructed in the lambda expression vector ZipLox (Life Technologies Inc., Gaithersburg, MD). The lambda phage was grown in Escherichia coli Y1090 (ZL) (Life Technologies Inc.) and positive clones were plaque purified by secondary and tertiary screening. Hybond XL membrane (Amersham, Piscataway, NJ) plaque lifts were hybridized at $42^{\circ} \mathrm{C}$ overnight with the denatured probe in hybridization buffer $(6 \times$ SSC $[1 \times$ $\mathrm{SSC}$ is $0.15 \mathrm{M} \mathrm{NaCl}$ plus $0.015 \mathrm{M}$ sodium citrate], $5 \times$ Denhardt's solution, and $0.5 \%$ SDS). Positive clones were recovered in the vector pZL1 by excision "in vivo" in E. coli DH 10B (ZIP) (Life Technologies Inc.) and were sequenced. One cDNA clone having the entire victoriocin precursor coding region was chosen as the standard template for preparation of random-primed $\left[\alpha-{ }^{32} \mathrm{P}\right]$ dCTP-labeled probes by PCR amplification with gene-specific primers GSP4-F and GSP2-R (Table 1).

Genomic DNA isolation. Genomic DNA of $H$. victoriae strains A-9, B-2ss, 408, and Penicillium chrysogenum was purified from freeze-dried mycelium pulverized in liquid nitrogen. DNA extraction buffer (50 mM Tris-HCl, $\mathrm{pH} 8.0 ; 50$ mM EDTA, $\mathrm{pH} 8.0$; $0.5 \mathrm{M} \mathrm{NaCl}$; and $1 \% \mathrm{SDS}$ ) heated to $65^{\circ} \mathrm{C}$ was added to the mycelium and the resulting slurry was extracted with phenol/ chloroform/isoamyl alcohol (25:24:1, vol/vol/vol). The DNA was precipitated with isopropanol, spooled onto a glass rod, washed with $70 \%$ ethanol, and air dried. The spooled DNA was resuspended in Tris-EDTA buffer with added RNase A. To verify the presence of a gene coding for the victoriocin precursor protein in $H$. victoriae, DyNAzyme DNA polymerase and the genespecific primers GSP4-F and GSP2-R (Table 1) were used in PCR amplifications of total DNA from A-9, B-2ss, and 408. Genomic DNA from $P$. chrysogenum was also used in search of homologs to the gene coding for victoriocin.

Southern hybridization analysis. In all, 4 to $10 \mu \mathrm{g}$ of genomic DNA of strains A-9, B-2ss, and 408 of $H$. victoriae and of $P$. chrysogenum were digested with EcoRI, HindIII, PstI, or XhoI overnight and the digestion products were size fractionated by electrophoresis in $0.7 \%$ agarose gels at $36 \mathrm{~V}$ for 16 to $20 \mathrm{~h}$. The DNA was transferred to Hybond $\mathrm{N}^{+}$nylon membranes (Amer- sham) and the membranes were dried at $55^{\circ} \mathrm{C}$ for $2 \mathrm{~h}$ and UV cross-linked. The blots were hybridized overnight at $42^{\circ} \mathrm{C}$ in hybridization solution (50\% formamide; $0.124 \mathrm{M} \mathrm{NH}_{2} \mathrm{PO}_{4}, \mathrm{pH}$ 7.2; 7\% SDS; and $10 \mathrm{mM}$ EDTA) with the denatured standard vin probe and washed with $2 \times \mathrm{SSC}$ at $42^{\circ} \mathrm{C}$ for $10 \mathrm{~min}, 2 \times \mathrm{SSC}$ at $65^{\circ} \mathrm{C}$ for $15 \mathrm{~min}$, and $0.1 \times \mathrm{SSC}$ and $0.1 \% \mathrm{SDS}$ at $65^{\circ} \mathrm{C}$ for $15 \mathrm{~min}$. The hybridized blots were exposed to a phosphorimager cassette and visualized with the PhosphorImager 445 SI system (Amersham).

Sequencing and sequence analysis. All PCR amplification products were ligated into the cloning vector pGEM-T Easy (Promega Corp., Madison, WI) and sequenced. Automated DNA sequencing was performed by dideoxy-termination sequencing using the Big Dye-terminator Sequencing Kit (Applied Biosystems, Foster City, CA) and an ABI 310 automated sequencer. Two to four independent clones of each PCR product were sequenced on both strands using M13 universal primers and gene-specific primers. The DNA sequences were analyzed using DNA Strider (CEA, France) and programs at the University of Wisconsin GCG software package, version 10 (12). Homology searches were conducted using BLAST, BLAST-N, and BLAST-P (1) programs in GenBank (www.ncbi.nlm.nih.gov). Searches for potential functional motifs and protein family signature patterns were performed using the programs in the servers for PredictProtein (42), ExPASy (18), and GenomeNet at the Bioinformatics Center, Institute for Chemical Research, Kyoto University (http:// genomenet.jp). Predictions of signal peptide and the most likely cleavage site were conducted using the SignalP 3.0 server (3). Protein cleavage sites were predicted using the PreP 1.0 server (13). Prediction of disulfide bonding of cysteine residues was performed using DISULFIND at http://disulfind.dsi.unifi.it (8).

\section{RESULTS}

Antifungal activity of $\boldsymbol{H}$. victoriae culture filtrates. The antifungal activity of culture filtrates of the virus-infected strain A-9 was readily demonstrated by the well assay (Fig. 1A). The culture filtrates of the virus-free strains 408 and B-2ss, on the other hand, showed no or negligible activities (Fig. 1A). The antifungal activity of culture filtrates of strain A-9 was also effective against a broad range of fungal and oomycete plant pathogens, including F. solani, Phomopsis longicola, Cryphonectria parasitica, Phytophthora parasitica var. nicotianae, Peronospora tabacina, and the opportunistic human pathogens $A$. fumigatus and Candida albicans. Interestingly, the virus-free and virus-infected isolates of $H$. victoriae showed little or no growth inhibition when tested in the well assay against culture filtrates of strain A-9 (data not shown).

The antifungal activity of culture filtrates from strain A-9 was retained after incubation on ice, at room temperature, and at temperatures of 37,50 , and $60^{\circ} \mathrm{C}$ for $1 \mathrm{~h}$ but not when the filtrates were incubated at $60^{\circ} \mathrm{C}$ for $2 \mathrm{~h}$. No activity was detected after incubation at temperatures of 70 to $99^{\circ} \mathrm{C}$ for $1 \mathrm{~h}$ or after autoclaving for $20 \mathrm{~min}$. Although the antifungal activity of untreated A-9 culture filtrates was resistant to pronase action $(10 \mathrm{mg}$ of pronase per $\mathrm{ml}$ of culture filtrate), a decrease in antifungal activity was evident when the filtrates were incubated either at $65^{\circ} \mathrm{C}$ for $1 \mathrm{~h}$ or in the presence of DTT at $0.5 \%$, prior to the addition of pronase (Fig. 1B). The results of heat and protease treatments of the culture filtrates suggested that the antifungal activity might be due to the presence of a stable protein or proteins in the filtrates. A multistep procedure involving ultrafiltration, ammonium sulfate precipitation, and two cycles of semipreparative RP-HPLC was used to purify proteins from the cultural filtrates (see Materials and Methods). The finding that the antifungal activity was consistently detected in the protein fraction recovered by ammonium sulfate precipitation is in agreement with a protein nature of the antifungal activity. 
The various RP-HPLC retention fractions were assayed for antifungal activity using the well assay. The results showed that fractions collected at 48, 50, and $51 \mathrm{~min}$ had the highest activity, as determined by the size of the inhibition zone of Penicillium chrysogenum. SDS-PAGE analysis of these three retention fractions revealed the presence of two major proteins, designated P10 and P30, with estimated sizes of 10 and $30 \mathrm{kDa}$, respectively (Fig. 2A). In western blot analysis, the antiserum prepared against P30 (AS-P30) reacted strongly with its homologous P30 protein and with some smaller proteins that may be products of limited proteolysis. AS-P30 did not react, however, with P10 (Fig. 2B). The antiserum prepared against P10 (AS-P10) reacted strongly with the homologous P10 protein and with larger, possibly related proteins but not with P30 (Fig. 2C). The nature of the P10-related larger proteins became evident when it was demonstrated that P10 is derived from a precursor protein. Several lines of evidence suggest that P10, which we designated as victoriocin, is the primary protein responsible for the antifungal activity in the culture filtrates and that it is derived from a preprotoxin (preprovictoriocin; see below and Discussion).

PCR amplification of cDNA sequences coding for victoriocin. Partial amino acid sequences of P10 (victoriocin) were obtained by automated Edman degradation sequencing. DOPPCR using degenerate primers Deg10-F and Deg10-R (Table 1), which were based on the sequences of two victoriocin internal peptides, GYDYDYG and PFVNADV (Table 2), resulted in a 78bp amplicon with a deduced amino acid sequence identical to that of these two internal peptides (underlined): GYDYDYGCDKG WCWRNCDGPFVNADV.

For amplification of sequences $3^{\prime}$ and $5^{\prime}$ of the DOP-PCR amplicon, a combination of PCR amplification of the cDNA obtained by reverse transcription of purified mRNA using genespecific and oligo(dT) primers and 5' RACE was used. Assembly of the nucleotide sequences of the 78-bp DOP-PCR amplicon and of the PCR products $3^{\prime}$ and $5^{\prime}$ of this amplicon resulted in a contiguous sequence with an open reading frame (ORF) coding for a protein of calculated molecular mass of $\approx 20 \mathrm{kDa}$. The entire coding sequence of the $20-\mathrm{kDa}$ protein was PCR amplified using genomic DNA of $H$. victoriae strains A-9, B-2ss, or 408 as templates and a pair of sequence-specific primers (GSP4-F and GSP2-R) (Table 1). No PCR products, however, were generated when full-length cDNAs of HvV190S and HvV145S dsRNAs or genomic DNA of $P$. chrysogenum were used as templates (data not shown). Taken together, these results support the conclusion that an endogenous host gene, vin, codes for victoriocin and that it is expressed in vivo as a $20-\mathrm{kDa}$-precursor protein. The sequences of the vin gene and flanking sequences were deposited in the GenBank under accession number EF587239.

Isolation and characterization of the vin gene. The HvcDNA library, generated in a previous study (51), was screened using a vin-specific probe. Fourteen independent cDNA clones with partial or full-length sequence of the coding region of the 20$\mathrm{kDa}$ protein were excised in vivo in the pZL1 vector in the $E$. coli excision strain DH10B (Zip) and sequenced. Comparison of the nucleotide sequences of the cDNA clones with the products of PCR amplification of genomic DNA indicated the lack of introns in the vin gene. The coding region for the $20-\mathrm{kDa}$ protein (victoriocin precursor) is 552 nucleotides in length (Fig. 3). A typical TATA box sequence (TATAAAT) was found $103 \mathrm{bp}$ upstream of the ATG triplet and a stress response element (STRE)-like sequence (TCAGGGGG) (48) was found 82 bp upstream of the TATA box (Fig. 3, printed in bold). The translation initiator sequence (underlined) CAAAATGA is present within the consensus sequence for filamentous fungi (5' CAMMATGNC 3', where $\mathrm{M}=$ A or $\mathrm{C} ; \mathrm{N}=\mathrm{A}, \mathrm{C}, \mathrm{G}$, or T) (2). This consensus sequence is also found in the gene coding for Hv-p68, an alcohol oxidase/RNAbinding protein of $H$. victoriae (51), and in genes of Neurospora crassa (14).

The vin ORF codes for a protein of 183 amino acids with calculated molecular mass of $19,493 \mathrm{Da}(20 \mathrm{kDa})$ and theoretical isoelectric point ( $\mathrm{pI}$ ) of 4.98 . The $20-\mathrm{kDa}$ protein was expected to be extracellular by PSORT prediction of protein localization, and SignalP 3.0 predicted a signal peptide cleavage sequence with a most likely cleavage site between $\mathrm{Ala}^{23}$ and $\mathrm{Val}^{24}$ (Fig. 3, arrowhead) in the sequence Ala-Glu-Ala/Val-Glu. The resulting processed protein (pro-victoriocin), which has a potential site for $\mathrm{N}$ glycosylation (Asn-Ser-Ser ${ }^{82}$ ), is predicted to have a calculated molecular mass of $17,267 \mathrm{Da},(17 \mathrm{kDa})$ and a theoretical pI of 4.96.

A putative cleavage site for a kexin-like processing protease with the sequence Ile-Ala-Lys-Arg ${ }^{97}$ (Fig. 3, underlined) was found 74 amino acids downstream of the signal peptide cleavage site, according to prediction of propeptide cleavage sites by ProP 1.0. This site is similar to the consensus cleavage site for the Kex2
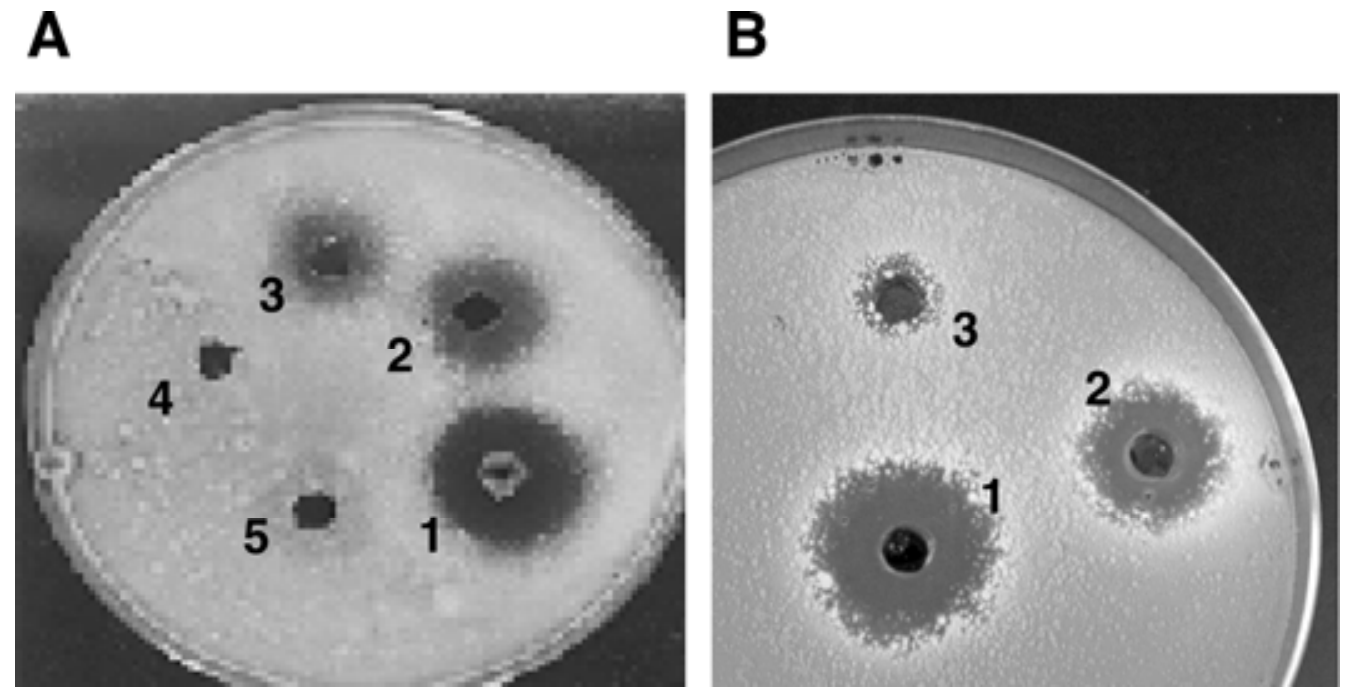

Fig. 1. Antifungal activity of Helminthosporium victoriae culture filtrates using the "well assay". Plates of potato dextrose agar, prepared in $0.05 \mathrm{M}$ citrate buffer, $\mathrm{pH} 4.5$, were seeded with spore suspensions of Penicillium chrysogenum, and wells were cut with a cork borer and filled with the assay solutions. A, Antifungal activity of twofold serial dilutions of culture filtrates of the virus-infected strain A-9 is demonstrated in wells 1-3. No antifungal activity was detected with culture filtrates of virus-free strains 408 and B-2ss (wells 4 and 5, respectively). B, Effect of pronase on the antifungal activity of culture filtrates from strain A-9. The culture filtrate was either untreated (well 1); heated at $65^{\circ} \mathrm{C}$ for $1 \mathrm{~h}$ (well 2); or heated at $65^{\circ} \mathrm{C}$ for $1 \mathrm{~h}$, after which pronase was added (and incubated for an additional $1 \mathrm{~h}$ at $40^{\circ} \mathrm{C}$; well 3 ) prior to filling the wells. 
proprotein convertase of Saccharomyces cerevisiae (Ali/Arg)Xaa-(Lys/Arg)-Arg $\downarrow$ (where Ali indicates an aliphatic amino acid) (43). Cleavage of the pro-victoriocin by a kexin or kexinlike protease may occur in a latter Golgi compartment to generate the mature victoriocin. The $\mathrm{N}$-terminal sequence (Fig. 3, amino

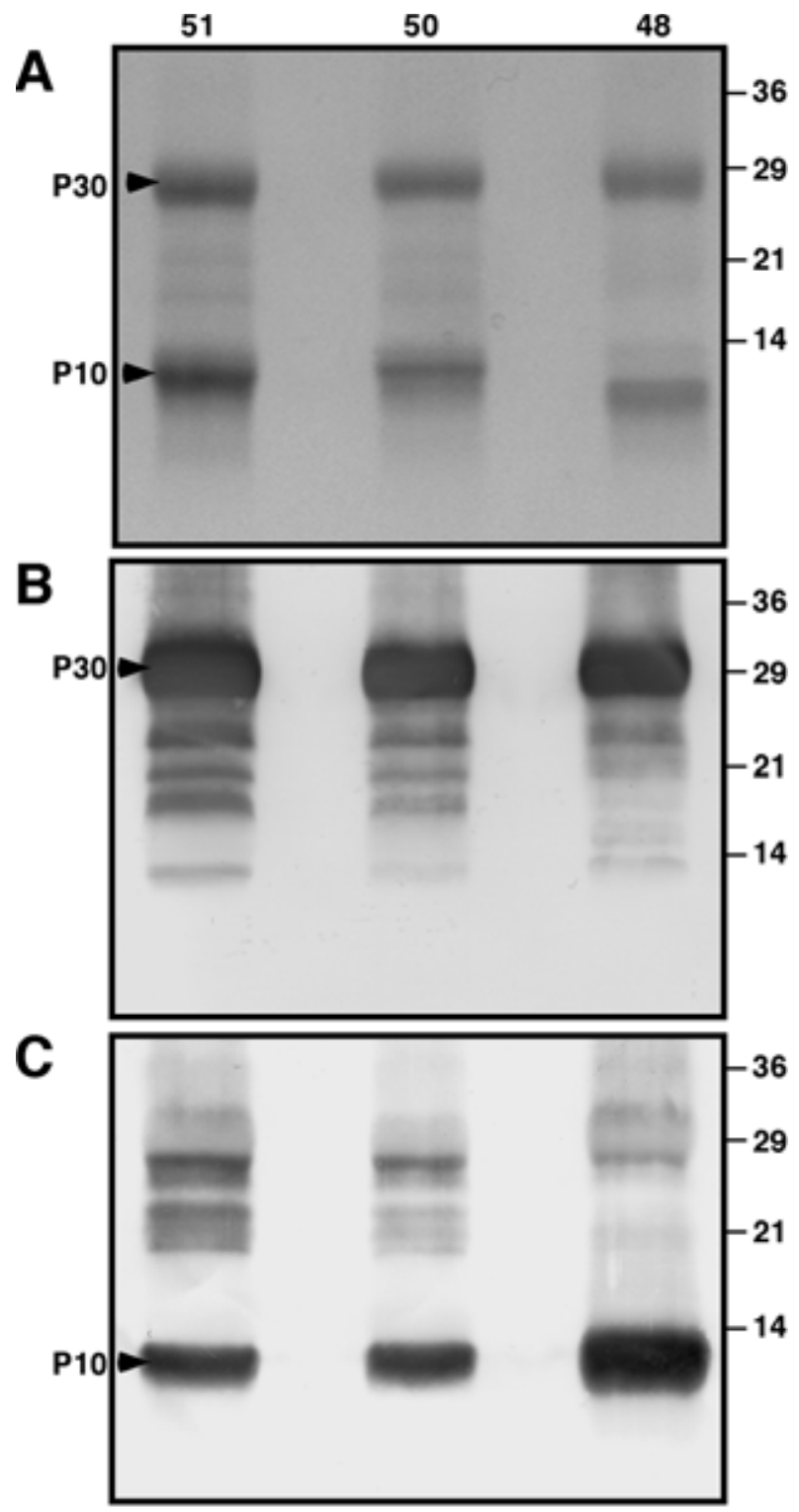

Fig. 2. Western blot analysis of two major proteins (P10 and P30) purified from culture filtrates of the virus-infected Helminthosporium victoriae strain A-9. A, sodium dodecyl sulfate polyacrylamide gel electrophoresis of reversephase high-performance liquid chromatography retention fractions collected at 48, 50, and $51 \mathrm{~min}$. The gel was stained with Coomassie blue and the positions of P10 and P30 proteins are indicated to the left. B and C, Proteins were transferred from replicate gels to polyvinylidene difluoride membranes and the membranes were probed with the antiserum to the $\mathbf{B}, \mathrm{P} 30$ or $\mathbf{C}, \mathrm{P} 10$ protein. acid positions 98 to 113 , shaded light gray) of the predicted mature victoriocin matches exactly the sequence of the purified P10 protein (victoriocin), as determined by Edman degradation sequencing (Table 2). Victoriocin has a calculated molecular mass of 9,372 Da and a theoretical pI of 8.01.

Structural and functional motifs found in victoriocin. A search for potential functional sites using Blocks+, a database of conserved regions in protein families (http://motif.genome.jp) (28), indicated that victoriocin has a short scorpion toxin family signature motif at its carboxyl terminal region with the sequence AKCGKGDCKA (Fig. 3, shaded; Table 3). Furthermore, victoriocin contains the consensus motif $\mathrm{Cys}^{\mathrm{I}}-(\mathrm{Xaa})_{\mathrm{i}}-\mathrm{Cy} \mathrm{s}^{\mathrm{II}}-\mathrm{Xaa}-\mathrm{Xaa}-\mathrm{Xaa}-$ $\mathrm{Cys}^{\mathrm{III}}$-(Xaa) $)_{\mathrm{j}}$-Gly-Xaa-Cys ${ }^{\mathrm{I}^{\prime}}-(\mathrm{Xaa})_{\mathrm{k}}-\mathrm{Cys}^{\mathrm{II}}-\mathrm{Xaa}-\mathrm{Cys}{ }^{\mathrm{III}}$ (Figs. 3 and 4) found in charybdotoxin and other neurotoxins isolated from venoms of scorpions and spiders (4). This consensus motif (Fig. 4), comprising the cytosine-stabilized $\alpha \beta$ motif (CS $\alpha \beta$ motif) $(9,32)$ and the $\gamma$-core motif $(57)$, is also shared by insect and plant defensins such as drosomycin and the Raphanus sativus antifungal protein 1 (Rs-AFP1), respectively $(15,38)$. The cysteine residues within the sequence motif in victoriocin were predicted to be bonded with a high degree of confidence (8) but the presence of a disulfide array similar to that found in the antifungal proteins drosomycin and Rs-AFP1 or in scorpion toxins $(4,9,15)$ remains to be confirmed.

In BLAST searches, the only known protein with significant amino acid sequence identity to the $20-\mathrm{kDa}$ protein (preprovictoriocin) was the IDI-2 precursor of Podospora anserina (accession no. AF500213) showing 31\% identity along a stretch of 161 amino acids. The IDI-2 protein, like victoriocin, is a small, cysteine-rich protein with a signal peptide. Interestingly, expression of three $i d i$ genes including idi-2 in P. anserina was shown to correlate with the cell death reaction associated with nonallelic vegetative incompatibility (5).

A Prosite motif search of the deduced amino acid sequence of the $20 \mathrm{kDa}$ indicated putative sites for protein kinase phosphorylation $\left(\mathrm{SSK}^{83}\right)$, a cell attachment site $\left(\mathrm{RGD}^{86}\right)$, a glycosaminoglycan attachment site $\left(\mathrm{SGNG}^{149}\right)$, four predicted casein kinase phosphorylation sites, and five predicted myristyolation sites.

Southern hybridization. Southern hybridization analysis of genomic DNA from $H$. victoriae strains A-9 and B-2ss, digested with EcoRI, HindIII, PstI, and XhoI, revealed similar restriction profiles (Fig. 5). However, the restriction profiles for the genomic DNA from strain 408 were somewhat different than those obtained for strains A-9 and B-2ss (Fig. 5). Similar results (differences in restriction profiles among strains) were obtained with the $H v-p 68$ gene (51). No hybridization signals were detected with Penicillium chrysogenum DNA.

Partial characterization of P30. A partial genomic clone of the P30 gene was generated by DOP-PCR using degenerate primers Deg30F and Deg30R (Table 1), which were based on sequences (underlined) derived from the N-terminus of P30, XDCNLPPISEAVVPGDVFKLVALPDVDNEIE, and from an internal peptide, VWLAGNDKPAGSEGCVELNAR, and using genomic DNA of strain A-9 as a template. DOP-PCR amplification resulted in an amplicon of 465 bp with a deduced amino acid sequence of 155 amino acids. The deduced amino acid

TABLE 2. Amino acid sequences determined by Edman degradation sequencing of the N-terminus and internal peptides of protein bands ${ }^{\mathrm{a}}$

\begin{tabular}{|c|c|c|}
\hline Protein bands & N-terminus sequences & Internal peptide sequences \\
\hline $10 \mathrm{kDa}$ & $\begin{array}{l}\text { XVCSKGGRGSGYDYDY } \\
\ldots \\
\ldots\end{array}$ & $\begin{array}{l}\text { GSGYDYDYGCDK } \\
\text { GWCWR } \\
\text { NCDGPFVNADVGLK }\end{array}$ \\
\hline $30 \mathrm{kDa}$ & $\begin{array}{l}\text { DCNLPPISEAVVPGDVFKLVALPDVDNEIE } \\
\text { DCNLPPISEAVVPGDVFK } \\
\ldots \\
\ldots\end{array}$ & $\begin{array}{l}\text { TTLPANIGR } \\
\text { XTETSPDNFEQEIXFTD } \\
\text { VWLAGNDKPAGSEGCVELNAR } \\
\text { NNLLIGDSFQSAXCTTR }\end{array}$ \\
\hline
\end{tabular}

a Degenerate primers were designed based on the amino acid sequences of the peptides printed in bold. 
sequence of this PCR product included the sequences of the peptides obtained by Edman degradation sequencing of the P30 protein. A search using BLAST (National Center for Biotechnology Information) of the deduced amino acid sequence revealed sequence similarity between $\mathrm{P} 30$ and PhiA cell wall proteins from several Aspergillus spp. (Fig. 6) including Emericella (Aspergillus) nidulans (37\% identity), A. fumigatus (37\% identity), A. clavatus (35\% identity), and the alkaline foam protein A precursor protein of $F$. culmorum (37\% identity). Furthermore, P30 contains the sequence motifs SGMGQG and ACP (Fig. 6, shaded and underlined) present in the highly conserved core region of "fungispumins", a recently described class of proteins (57).

\section{DISCUSSION}

There are a large number of known antifungal proteins that can be grouped into several classes, including killer proteins, defen- sins, PR-1 proteins, chitinases, chitin-binding proteins, protease inhibitors, lipid-transfer proteins, and others. These proteins are derived from wide-ranging sources, including bacteria, fungi, plants, insects, and animals (49). In the present study, we report the isolation and molecular characterization of a novel antifungal protein (victoriocin) that is secreted by virus-infected $H$. victoriae. Victoriocin has several features in common with the killer proteins secreted by totivirus-infected yeast and smut fungi. However, we have established that a host gene codes for victoriocin (the vin gene) whereas the yeast and smut killer proteins are encoded by satellite dsRNAs dependent on helper totivirus for replication and encapsidation $(47,56)$. The finding that culture filtrates of virus-free $H$. victoriae strains exhibit little or no antifungal activity suggests that overexpression of the vin gene is induced by virus infection. This idea is further supported by the discovery that overexpression of the vin gene in a virus-free strain of $H$. victoriae transformed with the vin gene mimicked the

\footnotetext{
CGTATATCATAGAACCACATTAGCCTGATCAGACTCTGATCATGAAAACCAACAGCATACACAGAATCTCAGGT $\quad-263$

CAGGGGGCCTCATGGAGCCGAGTTCGTCAAGCAACCACAAGGTCCTCTTCTGGCGAATATCCATAACAGCTTTACCAGA -189 GTGCTCAACGTATAAATGACATCTGCTACGCTGCCTGAATTCTACCACAGCTCTCAGCTACACAGACAACCATCATCAA -110

Fig. 3. Nucleotide sequence of the gene encoding the victoriocin precursor and its deduced amino acid sequence. A partial sequence of a cosmid clone containing the entire sequence of the victoriocin (vin) gene is shown. The coding region for the victoriocin precursor is 552 nucleotides in length and codes for a 183 -aminoacid protein. The ATG initiator and TGA terminator sequences are shown in bold and in italics. A typical TATA box sequence (TATAAAT) is present 102 bp upstream of the ATG triplet (printed in bold and underlined) and STRE stress response elements (CAGGGGG) are found 82 bp upstream of the TATA box (printed in bold). SignalP 3.0 predicted a signal peptide cleavage sequence with a most likely cleavage site between $\mathrm{Ala}^{23}$ and $\mathrm{Val}^{24}$ (arrowhead) in the sequence Ala-GluAla/Val-Glu (underlined). A putative cleavage site for a kexin-like processing protease with the sequence Ile-Ala-Lys-Arg ${ }^{97}$ (underlined) was found 84 amino acids downstream of the signal peptide cleavage site. The N-terminal sequence (amino acid positions 98-113, light gray) of the predicted mature victoriocin matches exactly the sequence of the purified P10 protein determined by Edman degradation sequencing. Victoriocin has a short scorpion toxin family signature at its

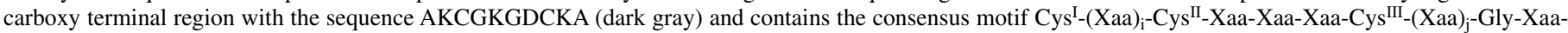
$\mathrm{Cys}^{\mathrm{I}^{\prime}}-(\mathrm{Xaa})_{\mathrm{k}}-\mathrm{Cys}^{\mathrm{II}}-\mathrm{Xaa}-\mathrm{Cys}^{\mathrm{III}}$ found in neurotoxins and defensins (the conserved glycine and cysteine residues are printed in bold and dark gray). 
effects of virus infection in inducing the overproduction and secretion of victoriocin and in enhancing the antifungal activity of cultural filtrates (11).

The mature Victoriocin $(10 \mathrm{kDa})$ is expressed in vivo as a 183 amino-acid preprotoxin precursor, $\approx 20 \mathrm{kDa}$ in size. The $20-\mathrm{kDa}$ preprovictoriocin has a predicted secretory pathway signal peptide, and cleavage between the $\mathrm{Ala}^{23}$ and $\mathrm{Val}^{24}$ releases a predicted proprotein of $17 \mathrm{kDa}$ into the secretory pathway. Further cleavage of the proprotein by a subtilisin/kexin-like proprotein convertase in the latter part of the Golgi complex is predicted to release the mature victoriocin of 86 amino acids with molecular mass of $\approx 10 \mathrm{kDa}$. The protease Kex 2 (kexin) of $S$. cerevisiae is the prototype of a family of serine proteases that process precursor proteins to active proteins in eukaryotes. It is a $\mathrm{Ca}^{2+}$-dependent transmembrane protease present in a trans compartment of the yeast Golgi that contains late-processing enzymes (7). Kex2 is necessary for the production and secretion of the mature $\alpha$ factor and killer toxins in $S$. cerevisiae at paired basic sites, optimally at Lys-Arg or Arg-Arg (41). Kexin-like proteins are ubiquitously found in eukaryotes and their occurrence in $H$. victoriae would be expected. The mature victoriocin and the predicted precursors (pro- and preprotoxin) (Fig. 7) were clearly detected in the virusfree $H$. victoriae isolates overexpressing the vin gene (11).

TABLE 3. Amino acid sequence motif found at the C-terminal regions of victoriocin and scorpion neurotoxins

\begin{tabular}{llc}
\hline Sequence motif & \multicolumn{1}{c}{ Toxin $^{\mathrm{a}}$} & Accession $^{\text {no. }}{ }^{\mathrm{b}}$ \\
\hline GKCMNKKCRC & Charybdotoxin & $\mathrm{P} 13487$ \\
AKCMNGKCKC & Toxin II & $\mathrm{P} 45630$ \\
AKCMNRKCKC & Pandinotoxin- $\beta$ & $\mathrm{P} 55928$ \\
AKCINKTCKC & Pi-4 & P58498 \\
AKCMNGKCKC & Margatoxin & $\mathrm{P} 40755$ \\
AKCINKSCKC & Maurotoxin & P80719 \\
AKCGKGDCKA & Victoriocin & B3F2Y6 \\
\hline
\end{tabular}

${ }^{a}$ Six scorpion toxins listed are charybdotoxin from Leiurus quinquestriatus var. hebreaus, toxin II isolated from Centruroides limpidus var. limpidus, two pandinotoxins (pandinotoxin- $\beta$ and Pi-4) from Pandinus imperator, margatoxin from C. margaritatus, and maurotoxin from Scorpio maurus var. palmatus.

b Accession number beginning with "P" from UniProtKB/Swiss_Prot and number beginning with "B" from UniProtKB/TrEMBL.
The similarities between victoriocin and zygocin, a monomeric protein toxin secreted by a totivirus-infected killer strain of the osmotolerant spoilage yeast Zygosaccharomyces bailii (40,55), are of considerable interest. Whereas the killer proteins of $S$. cerevisiae (K1, K2, and $\mathrm{K} 28$ ) and Ustilago maydis (KP1, KP4, and KP6) are active only against yeasts and smuts, respectively $(6,56)$, zygocin, like victoriocin, has a broad-spectrum antifungal

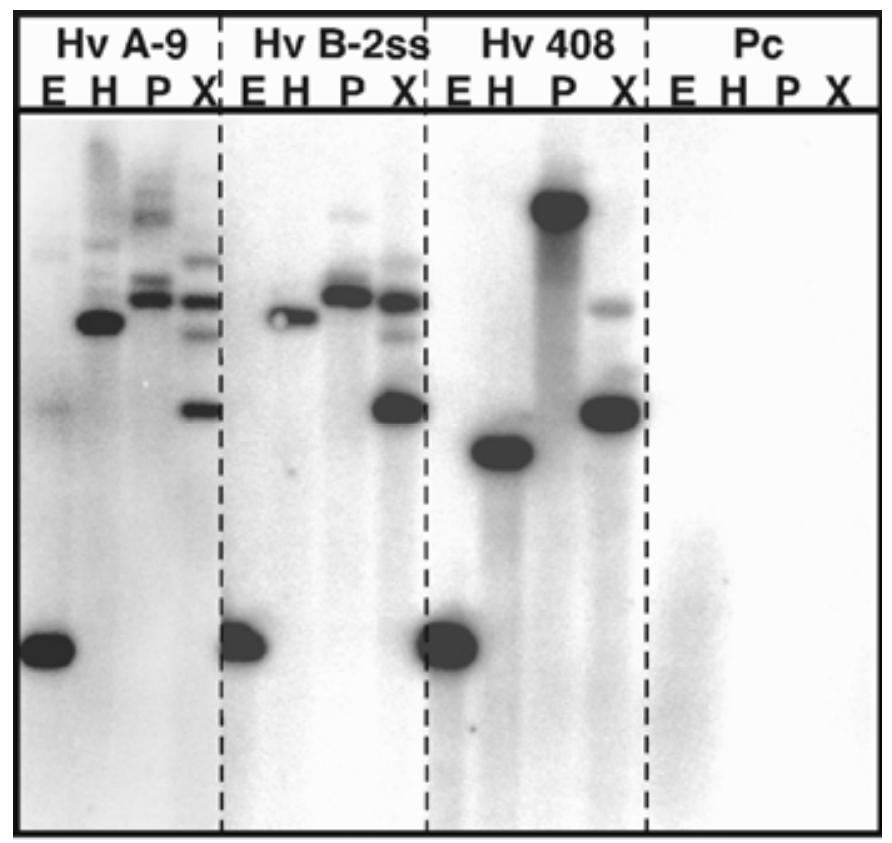

Fig. 5. Southern hybridization analysis of genomic DNA from Helminthosporium victoriae strains A-9, B-2ss, and 408 and from Penicillium chrysogenum digested with the restriction enzymes EcoRI (E), HindIII (H), PstI (P), and $\mathrm{XhoI}(\mathrm{X})$. The restriction fragments were separated on $0.7 \%$ agarose gels and transferred to Hybond $\mathrm{N}^{+}$membranes, which were hybridized with a ${ }^{32} \mathrm{P}$ labeled probe prepared by polymerase chain reaction amplification of the gene coding for victoriocin precursor using a cDNA clone as a template. Lanes: $\mathrm{Hv}$ A-9, H. victoriae strain A-9 infected with HvV190S and HvV145S; Hv B-2ss, a cured single-spore isolate of strain B-2; Hv 408, a naturally occurring virusfree isolate of H. victoriae; and Pc, P. chrysogenum.
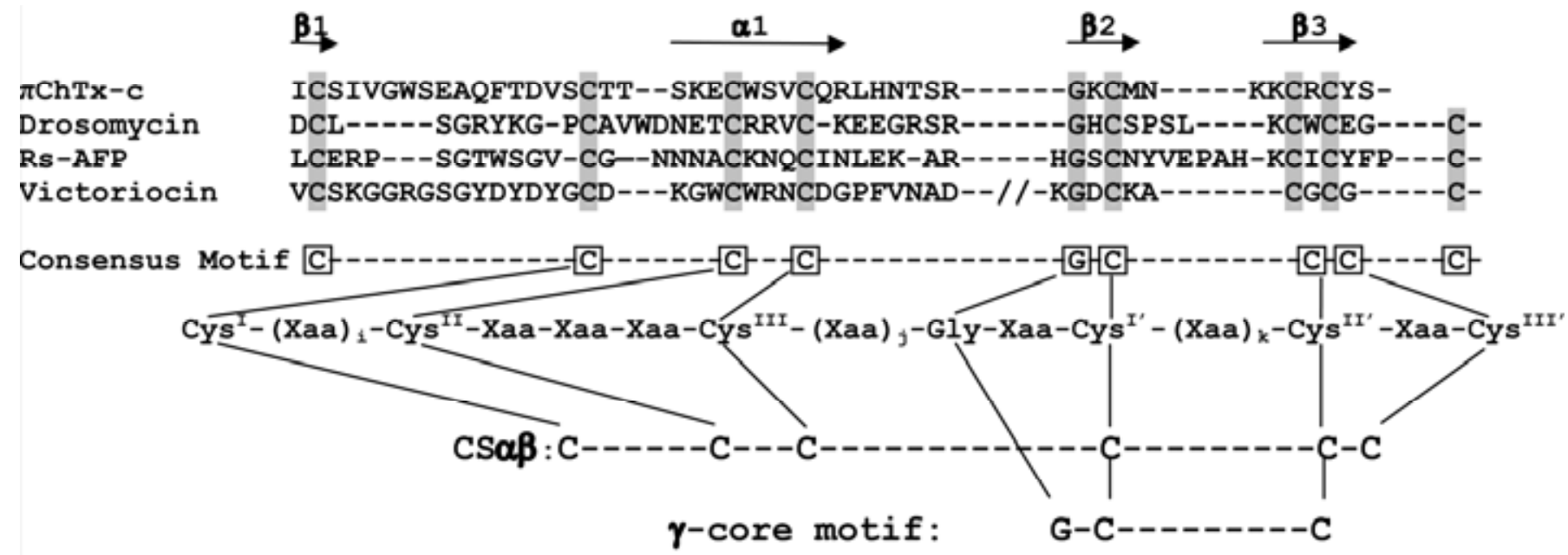

Fig. 4. Alignment of amino acid sequences of victoriocin, scorpion toxins, and plant and insect defensins showing the consensus motif Cys ${ }^{\mathrm{I}}-(\mathrm{Xaa})_{i}-\mathrm{Cys} \mathrm{s}^{\mathrm{II}}-\mathrm{Xaa}-\mathrm{Xaa}-$ Xaa-Cys $s^{I I I}-(X a a)_{j}-G l y-X a a-C y s^{I^{\prime}}-(X a a)_{k}-C y s^{I^{\prime}}-X a a-C y s{ }^{I I I}$. This motif is found in neurotoxins isolated from scorpions and spiders, drosomycin, and the plant defensin Raphanus sativus antifungal protein 1 (Rs-AFP1). Conserved cytosine residues are shaded and gaps (indicated by dashes) were introduced to maximize sequence similarity. Sequences used in the alignment were from ChTx-c, charybdotoxin from Leiurus quinquestriatus haebreus; drosomycin, a Drosophylla melanogaster defensin active against fungi; Rs-AFP1, R. sativus antifungal defensin; and victoriocin, antifungal protein from Helminthosporium victoriae. Boxes labeled $\mathrm{C}$ or $\mathrm{G}$ (under the alignment) designate conserved Cys or Gly within the consensus motif. Key residues corresponding to the CS $\alpha \beta$ motif common to defensins $(9,32)$, and the $\gamma$-core motif common to all classes of Cys-containing antimicrobial proteins (57) are shown at the bottom of the figure. Predicted secondary structures for densins and ChTx-c are indicated above the alignment $(4,32)$. 
activity against human and phytopathogenic yeasts and filamentous fungi (e.g., the plant pathogens $\mathrm{F}$. oxysporum and $\mathrm{Col}$ letotrichum graminicola). On the other hand, zygocin, like other killer proteins, is encoded by a satellite dsRNA that is dependent on a totivirus, Zygosaccharomyces bailii virus, for replication and encapsidation (47). Although there is a limited primary structure similarity ( $11 \%$ identity) between the two toxins, it is intriguing that the virally encoded zygocin and the chromosome-encoded victoriocin are so similar in their overall structure and hydrophobicity profiles (Fig. 7). Each preprotoxin consists of a hydrophobic N-terminal secretion signal, followed by a potentially $\mathrm{N}$ glycosylated pro-region and terminating in a classical Kex2p endopeptidase cleavage site that generates the $\mathrm{N}$-terminus of the mature and biologically active protein toxin in a late Golgi compartment $(47,53-55$, this study). The conspicuous similarity of these two proteins, both secreted, both processed by signal peptidase and kexin-like protease, suggests that the zygocin toxin might have been captured by the virus from a cellular transcript, because the victoriocin protein is encoded by a nuclear gene. Another excellent example in this regard is the chromosomally encoded heterodimer toxin salt-mediated killer (SMK) toxin, produced by the halotolerant yeast Pichia farinosa (33) and the virally encoded yeast killer K1. Although there is no sequence similarity to other toxins, the SMK preprotoxin resembles the $S$. cerevisiae $\mathrm{K} 1$ toxin in overall structure, hydrophobicity profile, and processing. Interestingly, the viral gene coding for $\mathrm{K} 1$ conserves the polyA stretch it putatively derived from the $3^{\prime}$ end of cellular messenger RNAs as an internal region of the viral plus strand.

Victoriocin has some similarities to the killer protein KP4 of $U$. maydis in that both are small, basic secreted proteins $(\approx 10 \mathrm{kDa}$ in size), resulting from processing of precursor proteins. Furthermore, victoriocin and KP4 are very resistant to temperature inactivation and proteolytic enzymes because they both are cysteine rich and stabilized by multiple disulfide bridges. Moreover, each has a short scorpion toxin family signature found in toxins of scorpions, spiders, and plant and insect defensins such as RsAFP1 and drosomycin, respectively $(17,38)$. Victoriocin differs from KP4 in that it is processed by a kexin-like endopeptidase. Unlike the smut KP1 and PK6 toxins, there is some information on the mode of action of KP4 because it has been shown to interfere with the function of calcium channels in both susceptible fungal cells and mammalian cells $(16,27)$.

As mentioned earlier, victoriocin has a short scorpion toxin family signature motif at its carboxyl terminal region. Furthermore, it exhibits the conserved $\operatorname{CS} \alpha \beta$ and $\gamma$-core motifs common to members of the scorpion toxin-like family (Fig. 4). Scorpion toxins are part of one of the functionally most diverse structural superfamilies in single-domain proteins, most of whose functions are associated with host defense mechanisms. Membrane channels are a major target for the various toxins produced by scorpions and other venomous animals (10) and it has been demonstrated that toxins with unrelated structures and similar functions have conserved functional residues and may have evolved convergently (10).

Victoriocin shares structural and functional motifs with defensins, which represent a diverse set of antimicrobial peptides known to be part of the innate immune systems of eukaryotes. Defensins are active against fungi, bacteria, and viruses. These small proteins are characterized by an N-terminal signal sequence, a highly divergent mature protein with the exception of conserved cysteine residues, and the presence of defensin motifs. Victoriocin is also characterized by an $\mathrm{N}$-terminal signal peptide and shares the conserved $\mathrm{CS} \alpha \beta$ and $\gamma$-core consensus motifs, characteristics of defensins (Fig. 4). Because defensin expression can be induced by pathogen inoculation and environmental stress, victoriocin may be viewed as an inducible fungal defensin that is induced by virus infection. Insect and mammalian defensins but not plant defensins are known to form voltage-regulated multimeric channels in the membranes of susceptible cells. The mode of action of victoriocin, like many antifungal proteins, is not known. However, considering its similarities to some killer proteins (e.g., zygocin and KP4), defensins, and neurotoxins, it is expected to target cytoplasmic membrane functions by forming cation-selective ion channels.

P30, which co-purifies with victoriocin, shares sequence similarity with PhiA cell wall proteins from several species of Aspergillus (Fig. 6) and with AfpA of F. culmorum. PhiA is involved in phialide development in A. nidulans and is overexpressed in response to treatment with bafilomycin, which has

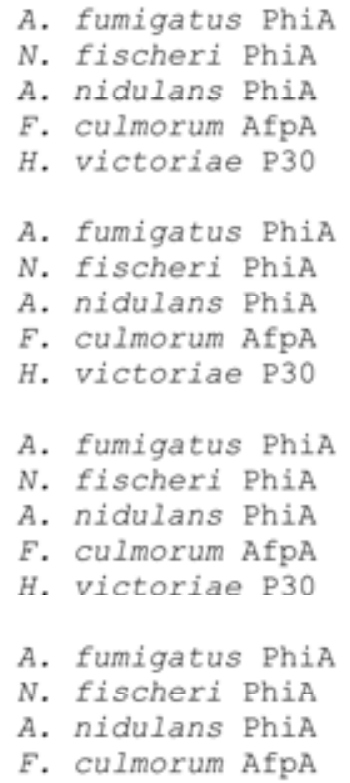

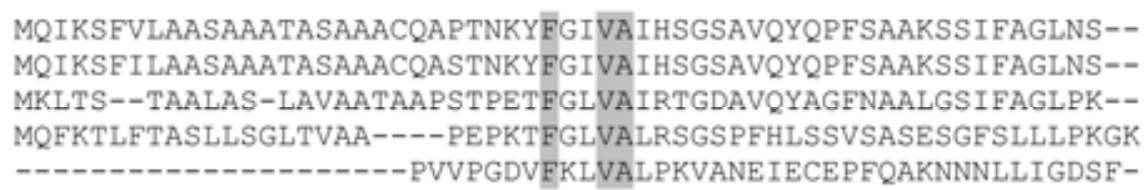

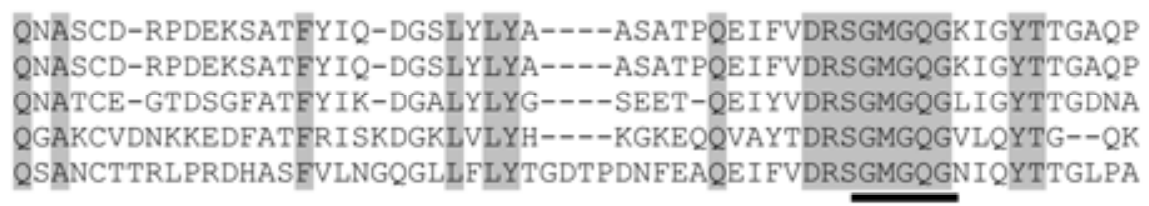

-APRNSER RQGWAIDSQNHLQF̄QGK-----DLIACPNSIDGAW-SIWADAGVANPAGN-TDCVG -GPKNSERQGWAIDDQNHLQFQGK-----DLIACPNSIDGAW-SIWADAGVANPAGN-KDCVG SGPRNSERTGWSI DENNHLVFDGN------LIACPNSIDSAY-SIWASAGVANPGGN-KDCVG NYPRNAETEGWKVDKDGNLVFGSNNAGF---MACPGLKSTDPWSIWVATGTDHPGNSEKECYS NIGRNQELGPFKITETSDLVEDNGNGAVTAFOACPPADGDKLTG-WKVWLAGNDKPAG-----

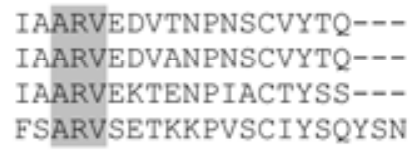

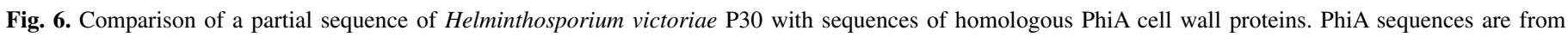

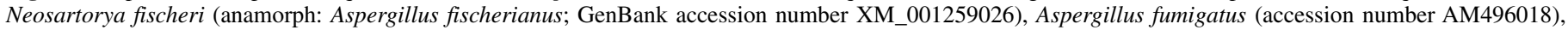

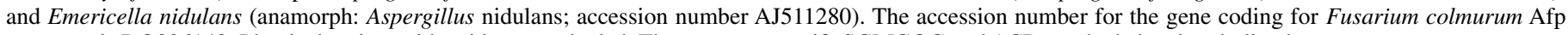
sequence is DQ336148. Identical amino acid residues are shaded. The sequence motifs SGMGQG and ACP are shaded and underlined. 
antifungal and antibacterial activities (37). Comparison of the sequences of $\mathrm{AfpA}$ and PhiA and other hypothetical proteins found in fungi has led Zapf et al. (58) to propose a new group of proteins, fungispumins, all of which share the highly conserved motifs SGMGQC and ACP in their core region (Fig. 6). Both of these two motifs are present in P30. The natural function of fungispumins remains to be elucidated. The role of P30, if any, in the antifungal activity exhibited by culture filtrates of virusinfected $H$. victoriae isolates is not clear. The overexpression of the cell wall protein P30 may represent an indirect response to the presence of the secreted antifungal protein victoriocin in a fashion comparable with the overexpression of the homologous PhiA proteins by Aspergillus spp. following treatment with the antifungal agent bafilomycin and the resultant inhibition of vacuolar ATPases (37). It would be of interest to determine whether overexpression of P30, a homologue of PhiA, plays a role in the
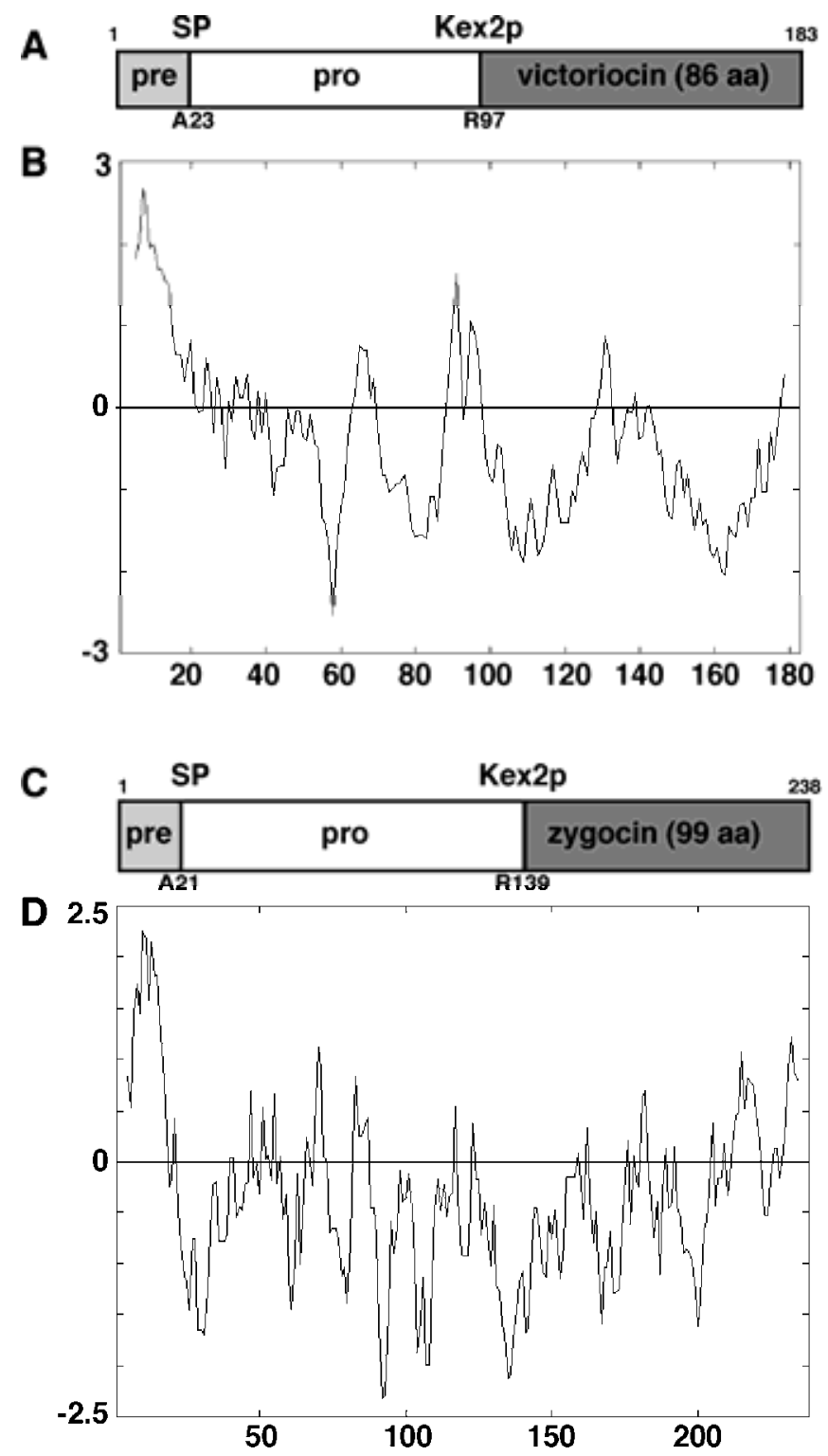

Fig. 7. Schematic representation and hydrophobicity profiles of preprovictoriocin (A and $\mathbf{B}$, respectively) and of preprozygocin ( $\mathbf{C}$ and $\mathbf{D}$, respectively). Processing sites are indicated by vertical lines with the name of the pertinent protease indicated above the diagram and the amino acid residue where cleavage occurs indicated below the diagram; signal peptidase (SP) and kexinlike protease (Kex2p). The Kyte-Doolittle algorithm (31) was used to plot hydrophobicity, with a window of 9 amino acids. Hydrophobic sequences are above the axis and hydrophilic sequences are below, with a maximum value of 3.0 or 2.5 (for victoriocin and zygocin, respectively) indicated on the scale. development of the disease phenotype (short, swollen hyphae) of the victoriocin-secreting, virus-infected $H$. victoriae isolates, considering the similarity in hyphal morphology between the disease phenotype in $H$. victoriae (25) and A. nidulans that overexpresses PhiA following treatment with the antifungal agent concanamycin (36). It is not known, however, whether the disease phenotype in $H$. victoriae is associated with inhibition of vacuolar ATPases. Future research will involve complete characterization of the $P 30$ gene as well as gene disruption studies in order to gain an insight into its role in the antifungal activity of the cultural filtrates and the disease phenotype in virus-infected $H$. victoriae isolates.

\section{ACKNOWLEDGMENTS}

This work was funded in part by grants (to S. A. Ghabrial) from the Kentucky Tobacco Research and Development Center and the Kentucky Soybean Promotion Board. This article is published with the approval of the Director of the Kentucky Agricultural Experiment Station (paper no. 10-12-028).

\section{LITERATURE CITED}

1. Altschul, S. F., Gish, W., Miller, W., Myers, E. W., and Lipman, E. M. 1988. Basic local alignment search tool. J. Mol. Biol. 215:403-410.

2. Balance, D. J. 1986. Sequences important for gene expression in filamentous fungi. Yeast 2:229-236.

3. Bendtsen, J. D., Nielsen, H., von Heijne, G., and Brunak, S. 2004. Improved prediction of signal peptides: SignalP 3.0. J. Mol. Biol. 340:783-795.

4. Bontems, F., Roumestand, C., Gilquin, B., Ménez, A., and Toma, F. 1991. Refined structure of charybdotoxin: Common motifs in scorpion toxins and insect defensins. Science 25:1521-1523.

5. Bourges, N., Groppi, A., Barreau, B., Clave, C., and Begueret, J. 1998. Regulation of gene expression during the vegetative incompatibility reaction in Podospora anserina: Characterization of three induced genes. Genetics 150:633-641.

6. Bruenn, J. 2004. The Ustilago maydis killer toxins. Top. Curr. Genet. $11: 157-174$

7. Bryant, N. J., and Boyd, A. 1993. Immunoisolation of Kex2-containing organelles from yeast demonstrates co-localisation of three processing proteinases to a single Golgi compartment. J. Cell Sci. 106:815-822.

8. Ceroni, A., Passerini, A., Vullo, A., and Frasconi, P. 2006. DISULFIND: A disulfide bonding state and cysteine connectivity prediction server. Nucleic Acids Res. 34:W177-W181.

9. Cornet, B., Bonmatin, J.-M., Hetru, C., Hoffman, J. A., Ptak, M., and Vovelle, F. 1995. Refined three-dimensional solution structure of insect defensin A. Structure 3:435-448.

10. Dauplais, M., Lecoq, A., Song, J., Cotton, J., Jamin, N., Gilquin, B., Roumestand, C., Vita, C., Medeiros, C. L. C., Rowan, E. G., Harvey, A. L., and Ménez, A. 1997. On the convergent evolution of animal toxins. J. Biol. Chem. 272:4302-4309.

11. de Sá, P. B., Li, H., Havens, W. M., Farman, M. L., and Ghabrial, S. A. 2010. Overexpression of the victoriocin gene in Helminthosporium victoriae enhances the antifungal activity of culture filtrates. Phytopathology 100:890-896.

12. Devereux, J., Haeberliy, P., and Smithies, O. 1984. A comprehensive set of sequence analysis programs for the VAX. Nucleic Acids Res. 12:387395.

13. Duckert, P., Brunak, S., and Blom, N. 2004. Prediction of proprotein convertase cleavage sites. Protein Eng. Des. Sel. 17:107-112.

14. Edelmann, S. E., and Staben, C. 1994. A statistical analysis of sequence features within genes form Neurospora crassa. Exp. Mycol. 18:70-81.

15. Fant, F., Vranken, W., Broekaert, W., and Borremans, W. 1998. Determination of the three dimensional solution structure of Raphanus sativus antifungal protein 1 by HNMR. J. Mol. Biol. 279:257-270.

16. Gage., M. J., Bruenn, J., Fischer, M., Sanders, D., and Smith, T. J. 2001. KP4 fungal toxin inhibits growth in Ustilago maydis by blocking calcium uptake. Mol. Microbiol. 41:775-785.

17. Gage., M. J., Rane, S. G., Hockerman, G. H., and Smith, T. J. 2002. The virally encoded fungal toxin KP4 specifically blocks L-type voltage-gated calcium channels. Mol. Pharmacol. 61:936-944.

18. Gasteiger, E., Gattiker, A., Hoogland, C., Ivanyi, I., Appel, R. D., and Bairoch, A. 2003. ExPASy: The proteomics server for in-depth protein knowledge and analysis. Nucleic Acids Res. 31:3784-3788.

19. Ghabrial, S. A. 1986. A transmissible disease of Helminthosporium victoriae: Evidence for a viral etiology. Pages 163-176 in: Fungal Virology. K. W. Buck, ed. CRC Press, Boca Raton, FL. 
20. Ghabrial, S. A. 2008. Totiviruses. Pages 163-174 in: Encyclopedia of Virology, Vol. 5, 3rd ed. B. W. J. Mahy and M. H. V. Van Regenmortel, eds. Elsevier, Oxford.

21. Ghabrial, S. A., Bibb, J. A., Price, K. H., Havens, W. M., and Lesnaw, J. A. 1987. The capsid polypeptides of the $190 \mathrm{~S}$ virus of Helminthosporium victoriae. J. Gen. Virol. 68:1791-1800.

22. Ghabrial, S. A., and Havens, W. M. 1989. Conservative transcription of Helminthosporium victoriae $190 S$ virus ds RNA in vitro. J. Gen. Virol. 70:1025-1035.

23. Ghabrial, S. A., and Havens, W. M. 1992. The Helminthosporium victoriae $190 S$ mycovirus has two forms distinguishable by capsid protein compositions and phosphorylation state. Virology 188:657-665.

24. Ghabrial, S. A., and Nibert, M. L. 2009. Victorivirus, a new genus of fungal viruses in the family Totiviridae. Arch Virol. 154:373-379.

25. Ghabrial, S. A., Sanderlin, R. S., and Calvert, L. A. 1979. Morphology and virus content of Helminthosporium victoriae colonies regenerated from protoplasts of normal and diseased isolates. Phytopathology 69:312-315.

26. Ghabrial, S. A., Soldevila, A. I., and W. M. Havens. 2002. Molecular genetics of the viruses infecting the plant pathogenic fungus Helminthosporium victoriae. Pages. 213-236 in: Molecular Biology of DoubleStranded RNA: Concepts and Applications in Agriculture, forestry and medicine. S. Tavantzis, ed. CRC Press, Boca Raton, FL.

27. Gu, F., Khimani, A., Rane, S. G., Flurkey, W. H., Bozarth, R., and Smith, T. J. 1995. Structure and function of a virally encoded fungal toxin from Ustilago maydis: A fungal and mammalian $\mathrm{Ca}^{2+}$ channel inhibitor. Structure 3:805-814.

28. Henikoff, S., Henikoff, J. G., and Pietrokovski, S. 1999. Blocks+: A nonredundant database of protein alignment blocks derived from multiple compilations. Bioinformatics 15:471-479.

29. Huang, S., and Ghabrial, S. A. 1996. Organization and expression of the double-stranded RNA genome of Helminthosporium victoriae $190 \mathrm{~S}$ virus, a totivirus infecting a plant pathogenic filamentous fungus. Proc. Natl. Acad. Sci. USA 93:12541-12546.

30. Huang, S., Soldevila, A. I., Webb, B. A., and Ghabrial, S. A. 1997. Expression, assembly and proteolytic processing of Helminthosporium victoriae 190S totivirus capsid protein in insect cells. Virology 234:130137.

31. Kyte, J., and Doolittle, R. F. 1982. A simple method for displaying the hydropathic character of a protein. J. Mol. Biol. 157:105-113.

32. .Lay, F. T., Schirra, H. J., Martin J. Scanlon, M. J., Anderson, M. A., and David J. Craik, D. J. 2003. The three-dimensional solution structure of $\mathrm{NaD} 1$, a new floral defensin from Nicotiana alata and its application to a homology model of the crop defense protein alfAFP. J. Mol. Biol. 325:175-188.

33. Magliani, W., Conti, S., Gerloni, M., Bertolotti, D., and Polonelli, L. 1997. Yeast killer systems. Clin. Microbiol. Rev. 10:369-400.

34. Matsudaira, P. 1987. Sequence from picomole quantities of proteins electroblotted onto polyvinylidene difluoride membranes. J. Biol. Chem. 262:10035-10038.

35. Meehan, F., and H. C. Murphy. 1946. A new Helminthosporium blight of oats. Science 104:413-414.

36. Melin, P., Schnürer, J., and Wagner, E. G. H. 2002. Proteome analysis of Aspergillus nidulans reveals proteins associated with the response of the antibiotic concanamycin A, produced by Streptomyces species. Mol. Genet. Genom. 267:695-702.

37. Melin, P., Schnürer, J., and Wagner, E. G. H. 2003. Characterization of phiA, a gene essential for phialide development in Aspergillus nidulans. Fungal Genet. Biol. 40:234-241.

38. Michaut, L., Fehlbaum, P., Moniatte, M., Dorssalaer, A. V., Reichhart, J.M., and Bulet, P. 1996. Determination of the disulfide array of the first inducible antifungal peptide from insects: Drosomycin from Drosophyla melanogaster. FEBS Lett. 395:6-10.

39. Psarros, E. E., and Lindberg, G. D. 1962. Morphology and respiration of diseased and normal Helminthosporium victoriae. Phytopathology 52:693-699.

40. Radler, F., Herzberger, S., Schönig, I., and Schwarz, P. 1993. Investigation of a killer strain of Zygosaccharomyces bailii. J. Gen. Microbiol. 139:495-500.

41. Rockwell, N. C., and Fuller, R. S. 1998. Interplay between $\mathrm{S}_{1}$ and $\mathrm{S}_{4}$ subsites in the Kex2 protease: Kex2 exhibits dual specificity for the $\mathrm{P}_{4}$ side chain. Biochemistry 37:3386-3391.

42. Rost, B., Yachdav, G., and Liu, J. 2004. The PredictProtein Server. Nucleic Acids Res. 32 (Web Server issue):W321-W326.

43. Rozan, L., Krysan, D. J., Rockwell, N. C., and Fuller, R. S. 2004. Plasticity of extended subsites facilitates divergent substrate recognition by Kex2 and Furin. J. Biol. Chem. 279:35656-35663.

44. Sanderlin, R. S., and Ghabrial, S. A. 1978. Physicochemical properties of two distinct types of virus-like particles from Helminthosporium victoriae. Virology 87:142-151.

45. Schaefer, B. C. 1995. Revolutions in rapid amplification of cDNA ends: New strategies for polymerase chain reaction cloning of full-length cDNA ends. Anal. Biochem. 227:255-273.

46. Schägger, H., and von Jagow, G. 1987. Tricine-sodium dodecyl sulfatepolyacrylamide gel electrophoresis for the separation of proteins in the range from 1 to $100 \mathrm{kDa}$. Anal. Biochem. 166:368-379.

47. Schmitt, M. J., and Breinig, F. 2006. Yeast viral killer toxins: Lethality and self-protection. Nat. Rev. Microbiol. 4:212-221.

48. Schüller, C., Brewster, J. L., Alexander, M. R., Gustin, M. C., and Ruis, H. 1994. The HOG pathway controls osmotic regulation of transcription via the stress response element (STRE) of the Saccharomyces cerevisiae CTT1 gene. EMBO J. 13:4382-4389.

49. Selitrennikoff, C. P. 2001. Antifungal proteins. Appl. Environ. Microbiol. 67:2883-2894.

50. Soldevila, A. I., and Ghabrial, S. A. 2000. Expression of the totivirus Helminthosporium victoriae 190 S virus RNA-dependent RNA polymerase from its downstream open reading frame in dicistronic constructs. J. Virol. 74:997-1003.

51. Soldevila, A. I., and Ghabrial, S. A. 2001. A novel alcohol oxidase/RNAbinding protein with affinity for mycovirus double-stranded RNAs from the filamentous fungus Helminthosporium (Cochliobolus) victoriaemolecular and functional characterization. J. Biol. Chem. 276:4652-4661.

52. Speicher, D. W. 1989. Microsequencing with PVDF membranes: Efficient electroblotting, direct protein adsorption and sequencer program modifications. Pages 24-35 in: Techniques in Protein Chemistry. T. Hugli, ed. Academic Press, San Diego, CA.

53. Weiler, F., and Schmitt, M. J. 2002. The Zygosaccharomyces bailii antifungal virus toxin zygocin: Cloning and expression in a heterologous fungal host. Mol. Microbiol. 46:1095-1105.

54. Weiler, F., and Schmitt, M. J. 2003. Zygocin, a secreted antifungal toxin of the yeast Zygosaccharomyces bailii, and its effect on sensitive fungal cells. FEMS Yeast Res. 3:69-76.

55. Weiler, F., and Schmitt, M. J. 2005. Zygocin-a monomeric protein toxin secreted by virus-infected Zygosaccharomyces bailli. Top. Curr. Genet. 11:175-187.

56. Wickner, R. B. 1996. Double-stranded RNA viruses of Saccharomyces cerevisiae. Microbiol. Rev. 60:250-265.

57. Yount, N. Y., and Yeaman, M. R. 2004. Multidimensional signatures in antimicrobial peptides. Proc. Natl. Acad. Sci. USA 101:7363-7368.

58. Zapf, M. W., Theisen, S., Rohde, S., Rabenstein, F., Vogel, R. F., and Niessen, L. 2007. Characterization of AfpA, an alkaline foam protein from cultures of Fusarium culmorum and its identification in infected malt. J. Appl. Microbiol. 103:36-52. 